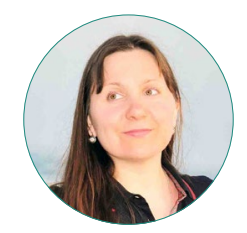

\author{
I. A. Antoshchuk
}

\title{
MOVING THROUGH THE STEM PIPELINE: A SYSTEMATIC LITERATURE REVIEW OF THE GENDER INEQUALITY IN RUSSIAN ENGINEERING
}

\section{For citation:}

Antoshchuk I. A. (2021) Moving through the STEM Pipeline: A Systematic Literature Review of the Gender Inequality in Russian Engineering . Monitoring of Public Opinion: Economic and Social Changes. No. 3. P. 57-87. https://doi.org/10.14515/monitoring.2021.3.1912.

Правильная ссылка на статью:

Антощук И. А. Продвигаясь по "трубе» STEM: систематический обзор литературы по гендерному неравенству в российской инженерной профессии // Мониторинг общественного мнения: экономические и социальные перемены. 2021. № 3. С. 57-87. https://doi.org/ 10.14515/monitoring.2021.3.1912. (In Eng.) 
MOVING THROUGH THE STEM PIPELINE: A SYSTEMATIC LITERATURE REVIEW OF THE GENDER INEQUALITY IN RUSSIAN ENGINEERING

Irina A. ANTOSHCHUK ${ }^{1}$ - PhD Candidate E-MAIL: irinantoschyuk@gmail.com https://orcid.org/0000-0001-8858-2815

${ }^{1}$ St Petersburg University, Saint Petersburg, Russia

Abstract. Gender inequality in engineering - and other scientific and technical fields - is one of the most persistent and intractable problems in modern culture. This issue has been sufficiently explored in Western Europe and the United States, but much less is known about the situation in Russia, which has a distinct gender history. In the former USSR, women were massively educated in technical sciences and their employment in engineering professions remained unconventionally high in comparison to the West. At the same time, women's earnings were lower than men's, and they mostly occupied low- and middle-level jobs, rarely reaching leadership positions. What happened to the gender imbalance after the collapse of the Soviet Union? How has it changed after radical political, economic, and social transformations? The purpose of this review, by analyzing empirical studies of gender inequality in engineering in post-Soviet Russia published after 1991, is to answer these questions.

In the last 15 years, there has been a growing interest and works dedicated to this topic, but they remain fragmented and disconnected.
ПРОДВИГАЯСЬ ПО «ТРУБЕ" SТЕМ: СИСТЕМАТИЧЕСКИЙ ОБЗОР ЛИТЕРАТУРЫ ПО ГЕНДЕРНОМУ НЕРАВЕНСТВУ В РОССИЙСКОЙ ИНЖЕНЕРНОЙ ПРОФЕССИИ

АНТОЩук Ирина Александровна - аспирант, Санкт-Петербургский государственный университет, Санкт-Петербург, Россия; аспирант, Университет Амстердама, Амстердам, Нидерланды E-MAIL: irinantoschyuk@gmail.com https://orcid.org/0000-0001-8858-2815

Аннотация. Гендерное неравенство в инженерном деле и других научнотехнических областях считается одной из наиболее устойчивых и трудноразрешимых проблем в современной культуре. Эта проблема достаточно изучена в Западной Европе и США, однако гораздо меньше известно о ситуации в России, которая отличается особой гендерной историей. В СССР женщины массово получали образование в области технических наук, а их занятость в инженерных профессиях была необычно высокой по сравнению с Западом. При этом женщины зарабатывали меньше мужчин и преобладали на должностях низкого и среднего уровня, редко достигая руководящих позиций. Что случилось с гендерным дисбалансом после распада Советского Союза? Как он изменился в ходе радикальных политических, экономических и социальных преобразований? Цель данного обзора - ответить на эти вопросы, анализируя эмпирические исследования гендерного неравенства среди инженеров в постсоветской России, опубликованные после 1991 г.

В последние 15 лет наблюдается рост исследовательского интереса к изучаемой нами теме, однако работы, посвя- 
Thus, there is a need for a generalized comparison of existing studies and the linking of them to one another. This systematic and problem-oriented literature review seeks to fill this gap. First, it aims to summarize, classify, and critically analyze the existing research results, thereby forming a general picture of gender transformations that have taken place in the engineering profession in Russia. Second, the review identifies key topics, issues, approaches, and reveals contradictions and gaps in the scientific discussion that enables a characterization of gender studies in the engineering field in Russia and formulates an agenda for future research. The review follows a STEM pipeline metaphor, organizing empirical findings in three stages: general education, professional education, and employment. Responding to the need for a comprehensive analytical perspective on gender inequality, the paper develops a multilevel framework, embracing and linking macro-, meso-, and individual-level causal factors of gender imbalance in engineering.

The main finding is that gender inequality dramatically increases from an individual's educational years to employment later in life, resulting in a multidimensional gender gap and multiple disadvantages for women. Path dependency on Soviet times has both positive and negative influences on gender equality, while the transition to a market economy has had mostly negative consequences, driving women out of engineering and leading to its masculinization. Another finding is that existing studies of the gender gap in post-Soviet Russia are not balanced, concentrating mostly on engineering education and initial professional socialization. More studies of the employment щенные ей, остаются фрагментарными и разрозненными. Поэтому ощущается необходимость в сравнительном анализе и обобщении существующих исследований, установлении взаимосвязей между ними. Данный систематический и проблемно-ориентированный обзор литературы призван восполнить этот пробел. Во-первых, обзор направлен на обобщение, классификацию и критический анализ существующих исследований, формируя тем самым общую картину гендерных трансформаций, произошедших в инженерной профессии в России. Во-вторых, он определяет ключевые темы, проблемы и подходы, выявляя противоречия и пробелы в научной дискуссии, что позволяет охарактеризовать состояние гендерных исследований в области инженерии в России и сформулировать повестку дня для будущих проектов в этой области. Обзор следует метафоре "трубы" STEM, группируя результаты эмпирических исследований по трем стадиям: общее образование, профессиональное образование и трудоустройство/занятость. Отвечая на потребность комплексного подхода к исследованию гендерного неравенства, я разрабатываю аналитическую рамку, охватывающую и связывающую его факторы на макро-, мезо- и индивидуальном уровне.

Основной вывод заключается в том, что от получения образования и до последующего трудоустройства гендерное неравенство нарастает и углубляется, что приводит к многомерному гендерному разрыву и формированию множества неблагоприятных для женщин условий. Зависимость от выбранного в советские времена пути оказывала как положительное, так 
and workplace period are necessary, as it remains the most troublesome for women. In addition to women-oriented comparative studies, the role of men's clubs, and norms of masculinity that support gender inequality need to be examined. More attention to macro-level factors and, most especially, the unique features of post-Soviet context is required.
Keywords: gender gap, factors of gender inequality, STEM pipeline, Post-Soviet context

Acknowledgments. The research was funded by the Russian Foundation for Basic Research (RFBR) according to the project № 20-011-00690: “Engineering career in contemporary Russia: professional, organizational, and institutional transformations". и отрицательное влияние на гендерное равенство, в то время как переход к рыночной экономике имел в основном отрицательные последствия, вытесняя женщин из инженерного дела и приводя к его маскулинизации. Другой наш вывод касается того, что существующие исследования гендерного разрыва в постсоветской России не сбалансированы и сфокусированы в основном на инженерном образовании и начальной профессиональной социализации. В связи с этим необходимы дополнительные исследования периода трудоустройства и работы, так как именно он остается наиболее проблемным для женщин. Помимо сравнительных исследований, ориентированных на женщин, нужно изучать роль "мужских клубов" и норм маскулинности, поддерживающих гендерное неравенство. Наконец, следует уделять больше внимания влиянию факторов макроуровня и в особенности уникальным чертам постсоветского контекста.

Ключевые слова: гендерный разрыв, факторы гендерного неравенства, "труба" STEM, постсоветский контекст

Благодарность. Работа выполнена при финансовой поддержке Российского фонда фундаментальных исследований (РФФИ) по проекту № 20011-00690: "Инженерная карьера в современной России: профессиональные, организационные и институциональные трансформации". 


\section{Introduction}

"There is no shortage of women in technology in Russia" proudly proclaims The Russia Times ${ }^{1}$ when discussing the fact that women constitute 41 percent of staff employed in scientific research in the country ${ }^{2}$. Russia is considered to be particularly "good at encouraging women into tech" ${ }^{3}$, stimulating girls' interest and confidence in STEM ${ }^{4}$ subjects from school to the workplace ${ }^{5}$. Such remarkable gender balance in science and technology is attributed as being a legacy of the Soviet state ${ }^{6}$, its "generalized efforts to improve the overall quality of instruction" in math and hard sciences $^{7}$, and support of women's employment in "government-funded facilities" 8 . In contemporary Russia, female technical specialists often deny specific difficulties related to their gender and believe women can achieve anything if they are motivated and professional. "If you love the work, everything is attainable. Gender has absolutely nothing to do with it" ${ }^{9}$, says Tatiana Korneeva, a young power engineer and a laureate of the prestigious national "Engineer of the Year - 2019" award ${ }^{10}$. Tatiana Rovenskaya, a successful scientist and technological entrepreneur, is also convinced that women are not disadvantaged: "The only obstacle I have encountered as a woman was competition - and that is same for men and women. In our country a clever woman does not feel undermined" ${ }^{11}$. "Compared to the rest of Europe, we just do not stress about “women's issues,'” agrees Alina Bezuglova, a producer of ZIMA StartUp contest, a cofounder of the technological conference EMERGE and RuTech project. She adds that she is inclined to think, "there is no problem at all" ${ }^{12}$.

Does this mean that equality - which seems so unattainable in other regions has come true in a one single country? Is it a long-lasting effect of a specific Soviet culture, which favored women's participation and realization in STEM [Gharibyan, Gunsaulus, 2006]? Or is it the consequence of the widespread “myth of gender equal-

\footnotetext{
${ }^{1}$ Why There's No Shortage of Women in Technology in Russia. (2017, May 26) The Russia Times. URL: http://www. russiatimes.org/women-in-technology-in-russia/ (accessed: 27.06.2021).

2 Science, Technology and Innovation: Women in Science. UNESCO Institute of Statistics. URL: http://data.uis.unesco. org/index.aspx?queryid=118\&export (accessed: 27.06.2021).

3 Bullock C. (2017, April 21) Why Is Russia So Good at Encouraging Women into Tech? BBC NEWS. URL: http://www.bbc. com/news/business-39579321 (accessed: 27.06.2021).

${ }^{4}$ STEM - Science, Technology, Engineering and Mathematics.

5 Ibidem.

6 Thornton A. (2019, March 05) Gender Equality in STEM Is Possible. These Countries Prove It. World Economic Forum. URL: https://www.weforum.org/agenda/2019/03/gender-equality-in-stem-is-possible/ (accessed: 27.06.2021).

7 Sylvester R. (2013, December 12) Russian Space History - Soviet Women in STEM Fields. Russian History Blog. URL: http://russianhistoryblog.org/2013/12/russian-space-history-soviet-women-in-stem-fields/ (accessed: 27.06.2021).

8 Thornton A. (2019, March 05) Gender Equality in STEM Is Possible. These Countries Prove It. World Economic Forum. URL: https://www.weforum.org/agenda/2019/03/gender-equality-in-stem-is-possible/ (accessed: 27.06.2021).

9 Here and further on translation of citations from Russian into English is made by the author.

10 "The Main Thing - To Love the Work You Do. There Is No Other Way". Interviews with the Young Laureates of the "Engineer of the Year - 2019" Award. (2020, February 21) Realnoe Vremya. (In Russ.) URL: https://realnoevremya.ru/ articles/166677-intervyu-s-laureatami-konkursa-inzhener-goda-2019 (accessed: 27.06.2021).

${ }^{11}$ Collinson S. (2016, March 08) Celebrating Women in Science and Technology on International Women's Day. SK Skolkovo. URL: http://sk.ru/news/b/articles/archive/2016/03/08/celebrating-women-in-science-and-technology-on-internationalwomen_2700_s-day.aspx (accessed: 27.06.2021).

12 Bullock C. (2017, April 21) Why Is Russia So Good at Encouraging Women into Tech? BBC NEWS. URL: http://www.bbc. com/news/business-39579321 (accessed: 27.06.2021).
} 
ity" [Khasbulatova, 2018] that was formed in the Soviet era and led professionals to neglect the problem of the gender gap, surrounding it with "deafening silence" [Lowrie, 2018: 37]? What is the actual state of gender (im)balance in engineering in Russia and how can it be explained? This paper sheds light on these questions by conducting a systematic review of scholarly literature on gender (in)equality in engineering in post-Soviet Russia.

In contrast to Western Europe and the United States - where this issue has been on the agenda for decades - in Russia it has started to attract attention only in 2000s. While there is a rich record of scholarship on the topic in the developed countries, scientific evidence on the situation in Russia has been accumulating only for the last fifteen years. It is versatile and curious, as well as inconsistent and fragmentary, covering some aspects of gender gap to a varying extent, but not producing a broader vision of changes that happened after the collapse of the USSR. In this review, I seek to summarize, connect, and critically analyze the existing research results, forming a general picture of gender transformations that have taken place in the engineering profession in post-Soviet Russia. Distinguishing several levels and group of factors that impact gender inequality among Russian engineers, I also propose a comprehensive conceptual framework and directions for future research.

\section{From the USSR to the Russian Federation}

In contrast to the developed Western countries - where women have been substantially underrepresented in STEM for years - the Soviet Union and then Russia have demonstrated a higher level of women's involvement in these spheres. From 1960 to 1970 , the number of higher education degrees in science, engineering, and technology increased dramatically (from 129,000 in 1960 to nearly 465,000 in 1974) ${ }^{13}$, resulting in a stable elevated share of women in research personnel ( $47-53$ percent) from the 1970s onwards [Pushkareva, 2010: 24]. The share of women in engineering in the Soviet Union is estimated to range from 20 percent in 1930s to 60 percent in 1980s [Uvarova, 2009: 31; Barabanova et al., 2013: 23.179.1; Kuznetsova et al., 2020: 56]. From 1960 to 1970 the number of women in engineering and the technical workforce in general grew from 1.63 to 3.75 million workers ${ }^{14}$. But the share of women, and the pace of growth, depended on the industry. For instance, in mechanical engineering women were a minority in 1932 (21 percent) but became almost half of the workforce by 1985 (45 percent) [Kuznetsova, Apevalova, Trofimova, 2020: 56]. Women have been significantly represented among Soviet programmers, forming an integral part of gender-mixed teams and collectives [Tatarchenko, 2017]. In other engineering specialties, such as chemistry and radiochemistry, women continuously represented a majority. Thus, they constituted 60-80 percent of chemical engineers and technicians at Soviet nuclear plants [Melnikova, 2017]. But despite substantial representation, women were concentrated mostly at middle- and low-level jobs, rarely achieving leadership positions [Mansurov, Yurchenko, 2016]; they were often delegated to paper and administrative tasks (deemed monotonous and routine work that demanded

\footnotetext{
${ }_{13}$ Sylvester R. (2013, December 12) Russian Space History - Soviet Women in STEM Fields. Russian History Blog. URL: http://russianhistoryblog.org/2013/12/russian-space-history-soviet-women-in-stem-fields/ (accessed: 27.06.2021).

${ }^{14}$ Ibidem.
} 
attention and accuracy and suitable for women) [Abramov, 2016, Melnikova, 2017]. The high level of women's involvement overall also did not automatically translate into a women-friendly workplace culture. Professional engineering culture acquired a masculine character, where appreciation of creativity, abstract mathematical thinking, and enthusiasm for tinkering with technology was coupled with an intensive regime of work, irregular hours, and night shifts [Abramov, 2016; Tatarchenko, 2017]. It latently favored men and disadvantaged women, pushing them out of the occupation or displacing them to the secondary roles. So, women in the USSR did acquire access to education and jobs in engineering and technology, but in spite of high representation the gender division of labor and gender segregation in these occupations were not overcome.

What occurred after the collapse of the Soviet Union? There is inconsistent and fragmentary evidence on this point. On the one hand, women's participation in STEM fields shows a tendency towards decline. The share of women in engineering and technology research gradually but steadily decreased from 41 percent in 2007 to 35 percent in $2015^{15}$. In 2018, the percentage of women in the highly skilled science and technology workforce amounted to only 31 percent ${ }^{16}$. The decrease of female engineers in the post-Soviet period is also partially confirmed by the analysis of VKontakte ${ }^{17}$ data [Rudenko, Maliushkin, 2021], showing that among the older generation professionally trained and socialized in the Soviet Union (50-60 years old) there were twice as many engineers as in the younger generation (approximately 30-years old) [Rudenko et al., 2019]. One of the important reasons driving the masculinization of engineering has been the reduction, due to economic crisis and stagnation, of female participation when "women were the first to be fired" [Uvarova, 2009: 31]. On the other hand, women's participation greatly varies across different engineering industries: women constitute only 13 percent of construction workers, 18 percent of the mining workforce, and 26 percent of specialists employed in the energy and power supply sector, but are more represented in manufacturing (38 percent) and water supply and waste disposal (31 percent) ${ }^{18}$. A decline in the share of women is reported in telecommunications, from 45 percent in 2005 to 38 percent in 2014, and in IT, from 35 percent in 2005 to 25 percent in 2014 [Shtyleva, 2018: 166] (though the proportion of women has grown in some IT occupations, including $1 \mathrm{C}$ software ${ }^{19}$ development, information security, and especially software testing) ${ }^{20}$. At the same time, women are reported to be severely underrepresented among highly qualified information technology professionals - only 17.5 percent in $2018^{21}$. Only chemical technology

\footnotetext{
${ }^{15}$ Science, Technology and Innovation: Women in Science. UNESCO Institute of Statistics. URL: http://data.uis.unesco. org/index.aspx?queryid=118\&export (accessed: 27.06 .2021 ).

${ }^{16}$ Calculations are Made by the Author Based on Official Statistics: The Number of Employed According to Gender and Types of Occupations in 2018. (2019) Labor and Employment in Russia in 2019. P. 32. (In Russ.) URL: https://rosstat.gov. ru/storage/mediabank/Trud_2019.pdf (accessed: 27.06.2021).

${ }^{17}$ One of the most popular a Russian-language social networking service.

${ }^{18}$ Calculations were made by the author based on official statistics: Ibidem. P. 27.

${ }^{19}$ One of the leading and widely spread accounting software in Russia.

${ }^{20}$ Dobrynina E. (2013, March 07) Women Choose “Male" Professions More Often. RG.RU. (In Russ.) URL: https://rg. ru/2013/03/07/professia-site.html (accessed: 27.06.2021).

${ }^{21}$ Calculations are made by the author based on official statistics: The Number of Employed According to Gender and Types of Occupations in 2018. (2019) Labor and Employment in Russia in 2019. P. 32. (In Russ.) URL: https://rosstat.gov.ru/ storage/mediabank/Trud_2019.pdf (accessed: 27.06.2021).
} 
continues to be dominated by women, as well as food and consumer goods technology, geodesy, and cartography [Kovaleva, 1999; Rudenko, Maliushkin, 2021]. Women still rarely achieve positions of leadership and authority and are often channeled into bureaucratic and other nontechnical work at the expense of complex technical tasks [Rudenko, Maliushkin, 2021].

This evidence suggests that there is a path dependence from Soviet times - a rather high level of women's participation, the persistent gender division of labor, and segregation. But we also observe a new tendency towards greater inequality and masculinization of the engineering profession. How can these trends be explained? What factors and conditions influence the gender (im)balance? What factors are specific to the post-Soviet context?

\section{Methodology}

I implemented a three-step approach in accomplishing a systematic literature review: identification of relevant literature; classification and systematization of the literature; and thematic analysis.

The first step was to identify relevant publications. The initial search was conducted at eLIBRARY.RU (www.elibrary.ru), the leading Russian-language electronic library of scientific periodicals, using a combination of keywords in Russian and English: "gender", “women”, "engineer", “STEM", "Russia”. Titles and abstracts of the publications found in the database were examined for relevance and works meeting the following criteria were considered relevant: (1) the work reports on the results of empirical research and is based on original empirical data; (2) the work analyzes gender differences and gender inequality/imbalance in engineering or engineering as part of STEM; (3) the work explores gender imbalance in the context of post-Soviet Russia. This excluded from review works containing general or theoretical contemplations on the subject, reviews of other literature, discussion of conceptual approaches or measurements, explorations of the particular experiences of women or men engineers, behavior or attitudes not linked to the gender gap, analysis of women's experience or gender imbalance in other professions and spheres of activity (science, police), and examinations of gender inequality in engineering faced by foreign nationals or migrant Russian-speaking engineers abroad. I also excluded works with fully repetitive data and findings, while in cases of partial intersection I included both publications. Empirical studies, which are focused on other issues - but contain findings related to gender disparity in engineering - are partially included in the review. Finally, using the initial body of literature deemed as relevant, I searched for additional works that satisfied the set criteria by examining: (1) the list of references indicated in the work, (2) the list of works citing the relevant paper or book, (3) other publications by the identified authors. For the second and third procedure I used the Google Scholar search engine and repeated the procedure with every new work until I ceased finding new titles and authors. As a result, I compiled a list of 42 papers, books, and conference papers.

The second step was to systematize and classify the selected literature and then divide it into groups. For this task I entered all relevant works in an Excel spreadsheet, indicating year of publication, discipline or research area, main themes and concepts prevailing in the text, type and details of empirical data, and major findings. Though I 
searched for studies published since 1991, I found that scientific research of gender inequality in Russian engineering has a shorter history. The first publications started to appear in 2006-2007 (four publications), followed by a break from 2009-2013 (two publications), followed by a slow rise between 2014-2016 (six publications), and then an outburst of interest over the last four years (thirty publications from 2017-2021). This means that the problem of gender inequality is currently peaking and is now attracting substantial scholarly attention. In terms of the discipline, the majority of works are sociological (twenty-eight publications), while some are related to both sociology and education studies (six), with fewer works related to psychology and sociology (two), psychology (two), anthropology (two), and science and technology studies (two). The majority of works are written either by two authors (nineteen papers) or a single author (fourteen papers), while the rest are written by three or more coauthors (nine papers). There are several research collectives or group of scholars which are actively engaged in publishing on the topic of gender inequality: L. N. Bannikova, L. N. Boronina, and E. V. Kemmet of Ural Federal University (ten publications), N. Rudenko, R. Maliushkin, and L. Zemnukhova at the European University at St Petersburg (four publications), O. B. Savinskaia, N. V. Lebedeva, and T. A. Mkhitarian at Moscow's Higher School of Economics University (HSE, four publications), A. A. Podolskaya at HSE, and V. I. Uvarova at Orel State Technical University (three publications). Thus, research is mostly concentrated in big cities and industrial regions. In general, papers are rather poorly cited: more than half of works (twenty-two) are not cited at all, a significant number of papers (sixteen) have a few citations (from one to eight), and only four publications are cited more than fifteen times. This perhaps means that there is insufficient communication among researchers engaged in gender inequality research, with scientists working in rather isolated collectives and not actively borrowing from the studies of others in the field.

Classifying the works according to the methodology, I divided quantitative, qualitative, and mixed methods studies. Half of the works (twenty-one) use quantitative methods and rely on survey data in their analysis, though large representative samples and big data are rarely used. Qualitative methods are less popular (thirteen papers), and fewer papers (eight) are based on a combination of methods (typically survey and interview materials). I do not call mixed methods studies because authors do not use this term and they either analyze each piece/type of data separately or unite them in an arbitrary way without an explanation of how they integrated different methods and why these particularly methods were selected.

In terms of theoretical approach, there is little diversity. The majority of works consciously or unconsciously adhere to constructivism (which they usually name as "gender approach"), treating gender as a "social status, which determines individual opportunities in education, professional activity, access to power, sexuality, family role and reproductive behavior" [Zdvaromyslova, Temkina, 1997: 84-85]. Some works demonstrate a lack of awareness about contemporary scholarly discussion — viewing gendered division of labor as rather natural and essentializing female gender role in society [Pavlov, Berdnik, Bondareva, Sheveleva, 2020]. The majority of works, explicitly or implicitly, adopt a framework of the STEM pipeline (or "leaky pipeline") to analyze gender imbalance in engineering. This framework presupposes that there are several 
successive stages of professional socialization and realization experienced by an engineer, characterized by different barriers and resulting in the attrition of potential professionals at every stage. The reviewed works probably borrow the concept from English scientific literature where it has remained "the dominant frame of inquiry" on this topic, though this concept has been criticized for the assumption of linearity and uniformity of STEM career pathways as well as encouraging simplistic policy responses [Cannady, Greenwald, Harris, 2014; Lykkegaard, Ulriksen, 2019].

Therefore, I group and classify the publications according to the stage of professional socialization and development in engineering they focus on: (1) works tracing the roots of gender inequality in the system of general and pre-professional training (secondary schools); (2) studies investigating gender (im)balance and reasons driving it in the system of professional training, mostly concentrating on university students (higher education); (3) studies focusing on women professionals and exploring gender disparity in the workplace, professional realization, and career; (4) studies discussing several periods separately or in connection to each other. I find that the majority of works examine gender disparities in higher education (twelve publications), while many works are devoted to gender inequalities in employment and professional realization (nine publications), and a few works devoted to secondary schools (four publications). A significant number of works analyze several periods simultaneously, typically higher education and the working place (eleven publications), while a few investigate general schooling and higher education (three publications) or combine data for all stages (three publications).

The third step was to conduct thematic coding and analysis of the selected literature. First, I read the publications to understand their main topics, questions, and results. Second, I extracted all the findings and divided them into three groups according to three stages of the STEM pipeline: general education, professional education, and employment. Third, I read the findings from each group separately, generating memos and codes for the main findings, categories, and explanatory variables. Fourth, I united codes into groups and, where appropriate, connected them with each other. In the next section I present the summary, reflections, and criticism of the findings in each group. Taking into account the criticism of using an individual-level lens to analyze gender inequality [Miner et al., 2018] and the argument "to adopt a multilevel perspective" [Lavigne, Rauvola, 2018], I develop and introduce a three-level framework (macro-level, meso-level, and individual-level) for analyzing causal factors of gender inequality in engineering in Russia.

\section{Results}

The roots of the problem? Looking at the system of general education

Studies document that the gender gap at the school level is very small, though some asymmetry is already observed. Analysis of data on pupils taking USE (Unified State Examination) in Russia shows that girls choose hard and natural sciences at the same level — or even more often — than boys [Shtyleva, 2018]. Moreover, except for math, in which girls and boys have the same achievements, girls generally get higher scores on their exams and surpass boys by $3-5$ points on average [ibidem]. So, in terms of general training, girls and boys are equally well prepared for subsequent 
professional training in engineering and STEM. But the gender gap is pronounced in specific contests where pupils are expected to solve nontrivial and creative tasks. Thus, in the Mathematics Olympiads, boys are the clear majority of participants (on average 86 percent vs 14 percent of girls) and winners (89 percent vs 11 percents of girls) [ibid.: 58].

Indeed, Shtyleva [2018] confirmed the crucial role of pedagogical culture in this respect (meso-level factor). Her analysis of the attitudes and perceptions of schoolteachers informing their teaching practices revealed that they share various stereotypes to their students, creating barriers for developing girls' interest and confidence in hard sciences. They often share and spread the view of the specific mathematical and liberal arts mindset and support the division of disciplines on "female" and "male" categorization. They are inclined to explain boys' achievements in math and other sciences by their talent and abilities, while attribute girls' success to their diligence and industry. In addition, teachers expressed the point of view that boys need to become professionals as they will be breadwinners and provide for the family, while girls will "give birth and forget math" [ibid.: 172]. The underrepresentation of girls in Olympiads is probably caused by teachers' reluctance to recommend and support girls taking part in these contests.

Another study identified the gap between girls' high achievements at school and the fact that they have lower confidence in math (individual-level factor) and subsequently rarely choose STEM for further education [Savinskaya, Mkhitaryan, 2018]. Already by $5^{\text {th }}$ grade far more boys (35 percent, compared to 8 percent of girls) choose technical disciplines for their future profession, while natural sciences are of interest to both boys and girls (29 percent versus 27 percent) [ibid.: 39]. As they grow older, girls demonstrate a gradual decline in confidence regarding their mathematical abilities (from 17 percent in $5^{\text {th }}$ grade to 10 percent in $11^{\text {th }}$ ); this contrasts with the experience of boys, who become surer of themselves (from 20 percent in $5^{\text {th }}$ grade to 38 percent in $11^{\text {th }}$ ) [ibid.: 39]. Interestingly, this process is not connected with the actual achievements of boys and girls: girls are getting better marks in the $5^{\text {th }}$ grade, but by senior classes both genders have the same level of performance [ibidem: 40]. Girls' lack of confidence in technical disciplines in senior classes was also documented in another study: 44-58 percent of girls doubt their abilities in these subjects, compared to 23-25 percent of boys [Savostina, Smirnova, Khasbulatova, 2017: 37].

There is a complex of factors - individual, family, class, and school environment that impact girls' preference and orientation towards engineering and STEM for the future career [Savinskaya, Mkhitaryan, 2018]. Girls do not choose STEM if they have a poor opinion about their abilities, do not get any help in math from their parents, study in a specialized "humanities" or "social-economic" classes, and when the whole organization of school life is gendered. On the contrary, girls choose STEM if they have high confidence in their abilities, their parents support them in fulfilling mathematical tasks, they study in a nonspecialized class, and attend a school where "gendered organization" of life is not prominent. Confidence level is probably the major underlying factor that influences girls' preferences; it tends to be higher when it is supported by parents and gender-neutral training, while gender-typing math and technology as male subjects is associated with traditional gender roles and lower confidence. Some 
of these findings resonate with other studies, which discovered that graduation from specialized physics and math schools is strongly associated with girls' choice of STEM in higher education, since it enables them to feel confident they can succeed in their studies [Bannikova, Baliasov, Kemmet, 2018; Bannikova, Kemmet, 2019a; Oblova, Gerasimova, Sishchuk, 2020]. Attending a specialized STEM class was shown to be associated with a much stronger girls' interest in STEM and technological professions, though they still did not get enough information about possible professional pathways [Kolesnikova, Kudenko 2020].

\section{Widening gender gap: professional training or higher education}

Varying underrepresentation of women

The majority of studies report some gender differences and asymmetry in higher technical education but they argue that the gender gap is not significant, though it tends to be greater than during general school years. Scholars assert that the problem of women's underrepresentation in higher education is less acute than in Western countries. Because of Soviet-era gender equality policies and the tradition of women actively participating in technical professional education, there are fewer barriers for women wishing to receive an engineering degree. Estimates of the proportion of women in the field vary depending on the data source and industry. Women accounted for 31-32 percent of engineering degree students in 1990s [Kovaleva, 1999: 427]. But women's representation varies greatly across different specialties. According to the 1990s data, women outnumbered men in chemical technology, food products and consumer goods technology, geodesy, and cartography [Kovaleva, 1999]. According to VKontakte data, women tend to concentrate in less technical engineering programs [Rudenko et al., 2019]. Women are also substantially represented in architecture and construction degrees (43 percent), but their share is much lower of information and computer technology degrees (26 percent) and even a lower percentage of energy and electrical engineering programs (20 percent) ${ }^{22}$ [Krekhovets, Leonova, 2017: 64]. Women are particularly underrepresented in rocket and space degrees (16 percent) ${ }^{23}$ [Podolskaya, 2020a: 155]. Data for earlier period (2011) shows a lower proportion of women in construction (30 percent), energy and electrical engineering (13 percent), and metallurgy, mechanical, and materials engineering (18 percent) [Kemmet, 2015: 56]. Thus, there is insufficient data for evaluating the dynamics of gender imbalance since the 1990s, but it is clear that women's underrepresentation in higher technical education is associated with industrial segregation, with school graduates channeled into respective "male" and "female" specialties. As a result, there are a few fields where women are well represented and many explicitly technical engineering programs where they are underrepresented.

How can this gender imbalance in higher education be explained? For the most part, studies seek to answer this question with individual-level factors, including such objective indicators as the level of pre-university training and performance at the university, and subjective characteristics such as motivation and value orientations,

\footnotetext{
$\overline{22}$ Data for 2014/2015.

${ }^{23}$ Data for 2015.
} 
self-confidence and anxiety, identification with engineering and determination to work in the profession, and general adherence to gender stereotypes. Interestingly, young women entering engineering degrees are better prepared than their male counterparts, with their grades on unified state exams and school certificates being higher [Kemmet, 2017; Bannikova, Kemmet, 2019b]. The possible explanation of this positive selection is that only young women with high grades have sufficient confidence to choose and apply to engineering programs. Alternatively, it might be a sign of the discriminative practices of admissions committees that favor male applicants with the same qualifications over female ones. Similarly to school dynamics, female students are reported to receive better scores and outperform male students at the university [Vysotskaya, Rusina, 2012]. Consequently, the dropout rate among female students is lower than among males [Vysotskaya, Rusina, 2012; Maloshonok, Shcheglova, 2020] and the proportion of women even increases by the final year. But the overall number of women in the profession dramatically decreases once they graduate from university and seek employment (see the next section for more details). Thus, the STEM pipeline leaks mostly at the point of transition from general to professional education and at the point of transition from academic training to employment, but not during university years. What are the causes of these leakages?

\section{Individual level factors}

First, scholars look for gender differences in the professional motivation: why young people choose engineering degree program, what motivates their studies, and what vision and expectations they have of their future profession. The majority of studies find that male and female applicants have similar motives, being attracted to attending a prestigious university more than by pursuing an engineering major. They view technical education as a high-quality universal education, which is sufficiently broad and flexible, bringing with it additional advantages on the labor market that make more likely a decent future income [Bannikova et al., 2018; Bannikova, Kemmet, 2019b; Bannikova, Boronina, Kemmet, 2016; Bannikova, Petrov, 2014]. Only two studies report that women and men choose engineering for different reasons, but their results are somewhat contradictory. Kemmet [2019] finds that female applicants are guided by their interest in engineering and the prestige of a university education, while males opt for engineering degrees in order to ensure a good income in the future. Other scholars report that women choose engineering because of the prestige of the profession and location of a university, while men have an interest in inventions and an engineering education [Mansurov, Yurchenko, 2017]. At the same time, there is ample evidence that, for young women who range from school graduates to master's students, the content of engineering profession is more important. They place more value on personal development and self-realization, creativity, and interesting tasks at work, while male students prioritize status considerations and demonstrate pragmatic interests such as getting a diploma and securing a good income in the future [Bannikova, Petrov, 2014; Bannikova et al., 2016; Bannikova et al., 2018; Vysotskaya, Rusina, 2012; Kemmet, 2017]. Young women have a more pronounced cognitive motivation and interest to interact with other people [Ivanova, 2006]. During university years, female and male students also develop similar expectations and attitudes towards their future work, 
wanting to realize themselves in the profession and build a career [Kislyakov, Shmeleva, 2018], though many students appreciate the lure of a stable and low-stress job that guarantees income, a comfortable work climate, and opportunity to balance work and family life. Thus, there are few gender differences in professional motivation, with young women being even more interested in realizing their creative potential in engineering than men. Given this, why do women often leave engineering after receiving a degree?

One of the factors influencing female students' intention for self-realization in engineering is their identification with the profession, but the available evidence on this point is inconsistent. Some studies report that young women are less determined to work in engineering after graduation than men [Kolesnikova, 2018]. Other scholars find that the share of males and females ready to stay in the profession versus changing their professional course and leaving the field is almost the same [Kislyakov, Shmeleva, 2018]. In some investigations, young women are found to demonstrate a stronger identification with the occupation and higher employability than men [Vysotskaya, Rusina, 2012]. Women pursuing master's degrees are more determined to work in engineering and persist in pursuing their professional ambitions [Bannikova et al., 2016; Kemmet, Bannikova, 2015; Bannikova, Petrov, 2014]. Undergraduate studies show they grew more confident in their abilities, but are still unsure about their employment chances and view their master's program as a sort of "safety cushion", a qualification which may help them find a good job in the "male field of engineering" [Kemmet, 2015; Kemmet, Bannikova, 2015]. Lack of confidence and uncertainty about future prospects remains a gendered problem in higher technical education that disproportionally affects female students. Young women demonstrate a higher level of anxiety throughout all years of their studies [Ivanova, 2006]. They expect to face challenges in finding a good job after graduation [Bannikova, Petrov, 2014], are more afraid of unemployment than males [Pavlov et al., 2020], and worry about the lack of practical experience and low salary to a greater extent than their male counterparts [Bannikova, Kemmet, 2019a, $2019 b]$. Thus, lack of confidence in one's abilities and future prospects is an important - and probably central - factor that weakens women's professional identities and their intentions to realize themselves in the profession. How to explain this lack of confidence among motivated and well performing female students?

\section{Meso- and macro-level factors}

Existing studies tend to suggest that persistent stereotypes regarding technology as a masculine domain and engineering as a male profession make the major contribution to this problem [Tiunova, 2020; Lebedeva, Savinskaya, 2019; Bannikova et al., 2018; Budnik, 2015; Myasina, Uvarova, 2007]. These visions are constructed in Internet forums, where stereotypes of women as "genetically unable to think as a creator and engineer" circulate (meso-level factor) [Budnik, 2015] abound. Online media also promotes men as "Russian engineers", "famous inventors and engineers in Russia", etc. National contests such as "Engineer of the Year" (macro-level factors) overwhelmingly feature men while paying scarce attention to women [Budnik, 2015]. Kemmet [2017] also underlines this lack of representation for successful female engineers. Partially gender-typing of engineering is reproduced and transmitted at the university level by faculty and fellow students (meso-level factors). When faculty 
view females as less capable in technology, they adopt a discriminative attitude and engage in the practice of othering women. They are either condescending and grant indulgences, or are more strict and demanding while lowering grades, marking women as unfit for the profession and advising them to leave the field [Lebedeva, Savinskaya, 2019; Savinskaya, Lebedeva, 2020]. In addition, a significant proportion of students, especially males, support the opinion that men are more talented in math and engineering then women [Maloshonok, Shcheglova, 2020]. Discriminative treatment from lecturers and students is also observed in IT programs [Tiunova, 2020]. Thus, during university women become increasingly subject to othering practices and made abundantly aware of the dominant vision of engineering as a gender-atypical occupation for them. Such sociocultural constructions of engineering may have a detrimental effect on women's confidence and their realization of careers in the profession, though women's responses vary. They either internalize and start sharing these stereotypes [Myasina, Uvarova, 2007], treat such discriminative practices as exceptional and not specific to technical education (and therefore of minor importance) [Tiunova, 2020], or they resist the stereotypes and othering by relying on the logic of professionalism and claim equality as professionals without gender [Budnik, 2015]. Internalization of stereotypes seems to be the most harmful. For instance, females who think their fellow students are convinced of males' superior mathematical abilities have a higher probability of being expelled from the university [Maloshonok, Shcheglova, 2020]. But whether other responses to discrimination give women any advantage by making them more resilient and successful in the profession is still a question to be explored.

What factors and circumstances help women to develop resilience and succeed in engineering degree programs? Bearing in mind that women are less confident in themselves and more susceptible to external evaluation [Ivanova, 2006], environment and significant others (meso-level factors) play a crucial role in this process. First, girls who study in specialized physics and mathematics schools/classes and attend study circles more often choose engineering degree programs because this environment enables them to develop their skills, interest in technology, and grow more confident to "excel in challenging and mathematically demanding disciplines" [Bannikova et al., 2018: 825; Bannikova, Kemmet, 2019a; Oblova et al., 2020]. Success in undergraduate degree programs also increases the confidence of women to apply for master's programs and increase determination to realize their professional goals [Bannikova et al., 2016; Kemmet, Bannikova, 2015; Bannikova, Petrov, 2014]. Second, parental influence is of central importance, especially parents' initial advice, support, and encouragement to pursue engineering degrees [Myasina, Uvarova, 2007; Bannikova et al., 2018; Bannikova, Kemmet, 2019b; Oblova et al., 2020]. Third, teachers at school arouse an interest in math and other relevant subjects [Myasina, Uvarova, 2007], then professors and supervisors at university [Myasina, Uvarova, 2007; Savinskaya, Lebedeva, 2020] support young women in their studies and research, motivating them to pursue a career in engineering. Finally, sometimes a specific university and program is chosen because of communication with a faculty member or admissions committee [Tiunova, 2020]. Nevertheless, there is a critical lack of specific support programs and initiatives at universities [Zakharova, Mkhitarian, Savinskaya, 2017; Bannikova et al., 2018], such as dedicated communities, fellowships, information campaigns 
(meso-level factors) that have proved their effectiveness at prestigious universities around the world and that might be very helpful in attracting and retaining women in the engineering field in post-Soviet Russia [Zakharova et al., 2017]. The organization of seminars and meetings with successful female engineers, as well as work in small groups, are also recommended as measures stimulating women's confidence and engagement [Maloshonok, Shcheglova, 2020].

In sum, gender inequality in higher technical education is not strong, but it is persistent, manifesting itself in gender segregation across engineering majors and women's underrepresentation in many specialties. The majority of studies seek to explain this gap in individual-level factors but find few gender differences in students' professional motivation and identity. Women are even more motivated by creative work and opportunities for personal development. In pre-university training and performance, young women also surpass men. But women demonstrate higher anxiety about professional prospects and a lack of confidence in their abilities. It seems to be mostly caused by gender-typing in the engineering field (particular in certain specialties) and the assumption that respective competencies are masculine, a tendency reproduced and supported by macro- and meso-level factors. Female students pursue different strategies of adaptation in response to such stereotypes, including complying with them, treating them as unimportant, or embracing the discourse of meritocracy and professionalism as an ideological tool for advancement. Although it is unclear whether these individual strategies benefit them and enable success, supporting environments on the meso-level (parents, faculty, specialized schools, certain university programs) definitely have had a positive impact, helping young women to become more confident, motivated, and determined to realize themselves in the engineering field.

The most "leaky" phase: solidification of gender imbalance in the workplace

Multidimensional and persistent inequality

Studies report a varying degree of gender imbalance among Russian engineers in their workplaces. Some studies reveal that the influence of gender is insignificant, with women hardly facing any obstacles for professional realization based on their gender while discrimination remains the exception rather than a rule [Tiunova, 2019, 2020]. Other scholars comment that women enjoy ample opportunities for professional development as ordinary specialists, but substantial barriers exist for women "who plan to climb up the career ladder" [Podolskaya, 2019: 206]. Nevertheless, the majority of studies report a pronounced gender imbalance among professional engineers in Russia, with employment and professional realization after graduation remaining the most challenging and "leaky" period for women.

I distinguished several dimensions of this imbalance:

- numerical disparity (men outnumber women)

- specialization ("male" and "female" fields)

- vertical segregation (men prevail in management positions)

- horizontal segregation (men are given more creative and complex work)

- remuneration gap (men earn higher salaries).

First, there is a numerical underrepresentation of women in engineering in general, though it is uneven across age groups and specialties. Analysis of VKontakte data 
shows that there is an approximately equal number of men and women studying for engineering degrees, but the number of women is considerably reduced once university graduates enter the labor market [Rudenko, Maliushkin, Zemnukhova, 2021; Rudenko et al., 2019]. Female engineers are less likely to gain employment compared to female economists, especially if they are married [Varshavskaya, Kotyrlo, 2019]. According to some data, about two-thirds of women with engineering qualifications leave the field for various reasons [Savinskaya, Lebedeva, 2020: 63]. Women are particularly outnumbered by men in the active-working age-group (30s), with twice as many men as women participating during this crucial phase of employment [Rudenko et al., 2021]. Among the older generation (50+), who were socialized in the Soviet Union, the number of men and women in the profession is more equal [ibidem]. As indicated earlier, this data might point to the greater gender equality among engineers during Soviet times, which contrasts with current trend towards masculinization in the field.

Second, specialization or industrial segregation manifests itself in the gendered profiles of certain specialties and occupations. Men prevail in occupations that presuppose direct work with technologies, machinery, and equipment, including "fancy" and high-tech fields (robotics, IT) that are more prestigious and highly paid (electronics, nuclear industry) [Rudenko, Maliushkin, 2021]. Women predominate in more non-technological engineering specialties such as chemistry, microbiology, and geodesy, and are more active in hybrid and lower status occupations [ibidem].

Third, women who stay in the field are subject to vertical segregation, being concentrated in low- and mid-level positions and encountering difficulties in advancing to senior leadership roles in organizations. They tend to stay in their current position for a longer period of time and are less often promoted than men [Podolskaya, 2020a; Podolskaya, 2020b; Mansurov, Yurchenko, 2017; Uvarova, 2009], who predominate in the management and executive positions that make promotion decisions [Bannikova, Petrov, 2014]. Thus, in Russian engineering, "glass ceiling" and "sticky floor" effects (well-known from English-language scholarly literature) are observed.

Fourth, there is a phenomenon of horizontal differentiation caused by the gendered division of labor within occupations and on the same organizational level. Women are more often allocated paper and bureaucratic work and assigned noncreative and monotonous tasks (which are necessary, but time-consuming and largely invisible and unrecognized) [Abramov, 2016, Podolskaya, 2019, Bannikova, Petrov, 2014]. At the same time, men appropriate the technical, complex, and creative tasks that receive more praise and recognition within enterprises [Podolskaya, 2019].

Fifth, there is some evidence of payment differential, with male engineers receiving higher salaries than women [Uvarova, Myasina, 2007; Kemmet, 2019], whose financial well-being remains rather modest [Mansurov, Yurchenko, 2017]. Thus, there is a strong and multidimensional gender imbalance in the engineering profession in post-Soviet Russia, which extends far beyond the problem of women's representation and reverberates across different industries and the corporate hierarchy.

Multiple, intersecting gender disparities point to a persistent and large-scale disadvantage for women. How does the available research account for this situation? Scholars discuss various factors, which I classify into three groups: macro-level (or structural) factors, meso-level factors, and individual-level factors. Structural or 
macro-level factors include legislation, the heritage of the Soviet Union, gender roles and norms, and gender typing of engineering and specific engineering professional competencies. Meso-level factors include organizational policies and working environment, the socio-psychological climate of the collective, intergroup (men versus women) and intragroup (women versus other women) competition, professional networks, and the influence of parents and other family members. Individual-level factors embrace personal interests and abilities, motivations and aspirations, value orientations, priorities, and beliefs. These factors are interconnected and interact, constituting stable configurations of conditions and circumstances, which determine barriers and opportunities for professional realization in engineering for women.

\section{Macro-level factors}

In terms of structural factors, scholars characterize contemporary Russian legislation as "gender-neutral" [Uvarova, 2009] and positively evaluate the legacy of the Soviet era, when "the state encouraged women to receive higher education and get employed in engineering" [Abramov, 2016: 101]. Though it is rarely noted, the division of engineering areas into "male" and "female" fields is also rooted in Soviet period. For instance, when chemical engineering became an overwhelmingly female sphere [Melnikova, 2017] programming was transformed into a male activity [Tatarchenko, 2017]. Horizontal and vertical segregation of women and men in engineering positions also was rather common and legitimate [Abramov, 2016; Melnikova, 2017]. Among other structural factors, scholars pay much attention to the negative effect of certain family gender roles and norms on the professional sphere.

First, despite the high employment rate among women and persistence of the working mother gender contract in post-Soviet Russia [Temkina, Rotkirch, 2002; Aivazova, 2011], men are still perceived as the main breadwinners, while women's contribution to the family budget is treated as secondary [Uvarova, Myasina, 2007]. Women are also assumed to take the ultimate responsibility for childcare, family management, and household duties. These gender roles and norms are used by organizations to justify higher salaries and quicker promotion for male professionals; this supports a gendered professional hierarchy that in turn contributes to the perpetuation of these norms. Surveys confirm that engineers are aware of these practices and do not disapprove them. Thus, an overwhelming majority of engineers (55-73 percent) think that career advancement is easier for men [Pavlov, Berdnik 2019: 292]; less than half of respondents (38-47 percent) believe the situation unjust when male colleagues get more payment for the same work and an even greater share of engineers support a higher salary for men (46-51 percent) over women (19-31 percent) [Pavlov et al., 2020: 668]. Thus, gendered roles and norms are supported and reproduced on the individual level. Such structural factors also result in problematic work-family balance, role conflict, and role overload realities that are particularly acute for women with children [Uvarova, Myasina, 2007; Podolskaya, 2019; Kemmet, 2019]. This often lowers women's status to second-rate workers and makes employers reluctant to recruit them, as they are thought to create additional difficulties and expenses [Kemmet, 2019]. This also affects value orientations and professional plans, leading to women abandoning career ambitions and becoming 
content with low- or mid-level positions. Thus, macro-level factors have implications for meso- and individual-level factors.

Second, there is a widespread and persistent gender-typing of engineering as a male profession and that professional competencies such as understanding technology, creativity, and decision-making abilities are masculine in nature [Kemmet, 2019; Uvarova, 2009; Mansurov, Yurchenko, 2017; Lebedeva, Savinskaya, 2019; Podolskaya, 2019; Podolskaya, 2020b; Bannikova, Kemmet, 2019a]. Women are seen as organized, careful, and responsible workers who are attentive to detail and good executors but who do not possess the professional qualities of inventors or leaders [Myasina, Uvarova, 2007; Podolskaya, 2019; Podolskaya, 2020b]. Many female engineers are continuously confronted with biased attitudes, sexist comments, and outright discrimination when looking for a job and in the workplace and many argue that these stereotypes impede their professional realization and career advancement [Budnik, 2015; Grigorieva, Chubarova, 2018; Myasina, Uvarova, 2007; Oblova et al., 2020; Podolskaya, 2020b]. Such forces push women out of explicitly technical and, especially, high-status occupations (for instance, programming) while justifying their being channeled into lower status jobs more bureaucratic and monotonous in character. Alternatively, some women attempt to position themselves as equal professionals by developing "masculine" professional traits and demonstrating "masculine" behavior at the workplace (toughness, goal-orientation, emotional coldness, etc.), while suppressing their femininity [Bannikova, Kemmet, 2019a; Podolskaya, 2020b]. In rare cases, the effect of occupational gender-typing might reduce the gender gap and be beneficial for women. For instance, testing is increasingly envisioned as a feminine occupation since involves more soft skills, is considered secondary to programming, and is friendlier in terms of the work-family balance [Zemnukhova, Guseva, 2019]. Many engineers, both women and men, internalize these stereotypes and consider men as innately more talented in technology and engineering [Mansurov, Yurchenko, 2017; Lebedeva, Savinskaya, 2019; Kemmet, 2019; Bannikova, Kemmet, 2019a], attributing this to "physiological capacities of brain activity" [Kemmet, 2019: 27]. In this way, gender stereotypes become internal barriers for women, "impacting their motivation and ambitions", while gender segregation is viewed "not as discrimination, but as a natural order of things" [Kozina, 2002: 127, 130].

\section{Meso-level factors}

Regarding meso-level factors of gender inequality, studies mention organizational policies, the sociopsychological climate in the collective, networks of professional contacts, and family support. The role of the organization is considered rather important, as it may have a decisive impact on reducing or sustaining the gender gap, but there is scarce evidence about the post-Soviet context on this point. If organizations intentionally or unintentionally support gender stereotypes in recruitment and promotion practices, it considerably constrains women's professional opportunities and sustains the gender gap [Kemmet, Bannikova, 2015]. If enterprises adhere to family-friendly policies, such as offering a package of medical and social services for families with children, it grants women more opportunities for balancing their professional and family roles and is thought to encourage greater professional involvement by women [Podolskaya, 2019]. 
But the effect on gender inequality is unclear. Do such policies reinforce the customary gendered division of labor, which assumes that women are in responsible for childcare and household management? Or do such policies stimulate more egalitarian distribution of unpaid and reproductive labor among men and women in the family, thus equalizing their chances for successful professional realization? These questions are to be explored in future research. I also found no studies of gender equality programs and their effects in organizations employing engineers, probably because there is still little awareness of the need to initiate and implement such programs. With regards to the role overload that women face as specialists, family support becomes an essential resource. The ability to work as an engineer and develop professionally often depends on the good will of women's partners/husbands and extended family networks that can fill women's role as mother and support their perseverance in making ends meet [Podolskaya, 2019; Kemmet, 2019]. In cases where family support is not garnered or possible, women may have to leave the engineering field [Grigorieva, Chubarova, 2018]. For women who stay in the profession, this double burden undermines their ability to build the professional networks vital for career development, since it is clear that "family obligations inevitably limit the possibilities for productive formal connections" and "minimize useful informal communication" [Uvarova, Myasina, 2007; Uvarova, 2009]. This is probably one of the reasons informal men's club among engineers act as a factor in professional advancement, since such networks shape men's preferences to spend time in one another's company, value the opinions of men, and promote other men [Myasina, Uvarova, 2007; Uvarova, 2009; Podolskaya, 2019; Podolskaya, 2020b]. In such settings they may also exchange jokes about women, reproducing stereotypes and sustaining male solidarity, while othering their female colleagues [Tiunova, 2019, 2020]. Some scholars view this as a result of intergroup competition, with men perceiving women as unwanted competitors in their "male" sphere of activity and squeezing them out by sticking together [Uvarova, Myasina, 2007; Myasina, Uvarova, 2007]. In addition, women have to compete with other women, undergoing intragroup competition that often "acquires more explicit and tough forms" than intergroup competition [ibidem]. A chilly or unfriendly atmosphere at the workplace can become an additional factor driving women out of the engineering profession [Kemmet, 2019].

\section{Individual-level factors}

Among individual-level factors, scholars explore the structure of motives, self-esteem, and satisfaction and identification with the profession. Regarding professional motivation, existing studies demonstrate divergent results. On machine-building enterprises, male engineers prioritize interest in their work and career and professional development opportunities [Dmitrieva, 2006], while female engineers also think it is important to practice their profession and raise their qualifications but appreciate much more positive working conditions and convenient hours [ibidem]. Nevertheless, young female engineers in the rocket and space industry demonstrate a different pattern of motivation, striving for professional development as well as higher salary, but typically have modest ambitions in terms of career advancement [Podolskaya, 2020a; Podolskaya, 2020b]. Women often are less satisfied with their work and position [Dmitrieva, 2006; Mansurov, Yurchenko, 2017], though female engineers who 
do not have career ambitions tend to be content with their job [Podolskaya, 2020b]. Several studies mention low self-esteem as a characteristic of female professionals [Kemmet, Bannikova, 2015; Savinskaya, Lebedeva, 2020], even when they have achieved high-powered positions [Uvarova, Myasina, 2007]. Women also demonstrate weaker identification with engineering compared to men. The overwhelming majority of men consider engineering as their calling and are sure they made the right choice, while women are less sure they would choose engineering again [Bannikova, Petrov, 2014; Mansurov, Yurchenko, 2017]. Sometimes the specificity of women's individual dispositions is interpreted as a subjective barrier that impedes the realization of their potential and drives them out of the profession. Women are viewed as less interested in promotion and trying to escape additional responsibility; therefore, they stay at low- and mid-level positions [Podolskaya, 2020a; Podolskaya, 2020b]. Women just prioritize comfort at work and family, while commitment to career advancement "impoverishes their emotional life" [Dmitrieva, 2006: 108]. But this individualization of gender gap does not seem fully justified, as it does not originate "in the choices, behaviors and expectations of individual women" but is a "a socio-structural problem" shared and maintained by all members of society [Miner et al., 2018: 285] — from the engineering workplace to the family circle and from the broader professional culture to general societal ideologies. Therefore, a more plausible interpretation is to treat individual-level factors as connected to and sustaining the effects of macro- and meso-level factors. Thus, the structure of women's motivation reflects their role overload and double work-family burden, as well as invisible but firm barriers to building their careers. As a result, women lower their ambitions and self-esteem [Savinskaya, Lebedeva, 2020; Kemmet, 2019]. Women's lower satisfaction and weaker identification with engineering signal that the profession in post-Soviet Russia remains not particularly friendly and encouraging field for females, even those who have already proved themselves as motivated and qualified.

\section{Specificity of post-Soviet context}

These factors, separately and in combination, create persistent problems that cause and sustain the gender imbalance found in engineering workplaces. Open and covert discrimination, systematic underestimation of abilities and contributions, and tensions due to balancing work and family roles are the most frequent issues women face in the engineering profession in Russia. These problems are not new or specific to Russian engineering, but there are certain conditions in the post-Soviet context that probably make them more acute and difficult to solve. First, there is a surprising inattention and absence of concern about discriminative discourses and practices in engineering. Declarations of gender equality and massive women's employment in the Soviet Union gave rise to a "myth of gender equality" [Khasbulatova, 2018], which is still powerful in contemporary Russia, despite the dominance of a working mother gender contract that disproportionally puts the load of family duties and childcare on women [Chernova, 2019]. The collapse of the Soviet Union was followed by a diversification of this gender contract [Temkina, Rotkirch, 2002] and revival of traditional ideals of the male breadwinner versus the housewife [Chernova, 2019]. Thus, in the post-Soviet Russia has emerged a peculiar combination of rhetoric proclaiming an 
achieved gender equality with ongoing cultural support for rather conservative gender roles and societal norms [Kravchenko, Motejunaite, 2008]. As a result, in the engineering profession "even direct discrimination" of women is "perceived by most actors on the labor marker as a matter of course" [Uvarova, 2009: 34]. Women are mostly satisfied with their situation [Podolskaya, 2020b], though much less than men [Mansurov, Yurchenko, 2017], and they do not feel a need for special support programs [Uvarova, 2009]. Meritocratic ideology and the discourse of professionalism - which prioritizes abilities, qualifications, and experience [Tiunova, 2019, 2020; Podolskaya, 2019] - often overpowers the raising awareness about gender inequality. It forces women to deny discrimination is occurring and to reject their femininity in order to preserve their status as a professional engineer, behaving as if an "engineer does not have a gender" [Podolskaya, 2019: 205].

\section{Conclusion}

Analysis of the existing empirical studies demonstrates that Russia hardly deserves a reputation as a progressive country with a high representation of women in technology. Gender inequality dramatically increases from school to the workplace, from minor differences in preferences and interests to a multidimensional gender gap, one in which women are not only underrepresented, but disadvantaged in terms of salary, opportunities for professional development, and career building. Persistent gender-typing of engineering as a male profession is a major contributor to this problem, driving women out of the field by weakening their identification with it, lowering their confidence, and negatively influencing their professional plans. These stereotypes are supported and reproduced in a variety of educational and organizational settings - through othering practices, discriminatory treatment, and sexist comments and jokes. While the gender gap in general and professional education is less pronounced, because these spheres are still very much path dependent on the Soviet era and are regulated by the state, the gap has become substantial in the more competitive and market-driven sphere of paid employment. Economic transformations were accompanied by shifts in state ideology and public discourse, with the commitment to gender equality replaced with neotraditionalism. In such conditions, women encounter more difficulties balancing their work and family life and are therefore more subject to discriminative treatment in the labor market. Thus, the collapse of the USSR widened the gender gap in engineering and led to the masculinization of the profession.

Seeking to explain gender inequality - and offer measures to overcome it - existing studies pay attention to meso- and individual-level factors, but structural factors remain insufficiently investigated. This does not enable the full examination of the effects of the Soviet legacy while taking into account the specific gender history of Russia to reveal the peculiarity of the post-Soviet context. The observed issues and problems associated with the gender gap are similar to those identified in Western contexts and are described with concepts and theories of Western science, though the unique features of gender inequality among Russian engineers are somewhat lost. One such trait is the lack of awareness by the general public and engineers themselves about the problem, which makes it more difficult to spot and solve. Belief in achieved gender equality means that the problem is ignored or rendered unimportant, while 
discriminative practices and discourses are normalized on the basis of essentialized gender. Regarding meso-level factors, there is a lack of studies on the effects of specific university and organizational programs that systematically support women, a lack of research on men's clubs and masculinities in engineering, the professional culture of engineering, and gendered discourses and media representations of engineering. More comparative studies are needed to trace the effects of gender separately pertaining to each factor and on specific stages of the STEM pipeline.

\section{References}

Abramov R. N. (2016) Professional Culture of Russian Technical Specialists: Universal Elements. Sociological Studies. No. 9. P. 96-104. (In Russ.)

Абрамов Р.Н. Профессиональная культура российских инженерно-технических специалистов: универсальные элементы // Социологические исследования. 2016. № 9. С. $96-104$.

Aivazova S. G. (2011) “Working Mother” Contract: Violations or a Breach? (On the Question of the Specificity of Gender Politics in the Contemporary Russia). Woman in Russian Society. No. 3. P. 13-22. (In Russ.)

Айвазова С. Г. Контракт "работающей матери»: нарушения или расторжение? (К вопросу об особенностях гендерной политики в современной России) // Женщина в российском обществе. 2011. № 3. С. 13-22.

Bannikova L. N., Kemmet E. V. (2019a) A Woman in the Man's Culture of Engineering Education. Higher Education in Russia. No. 12. P. 66-76. https://doi.org/ 10.31992/0869-3617-2019-28-12-66-76.

Bannikova L. N., Kemmet E. V. (2019b) Gender Analysis of Professional Potential of Future Engineers. In: Culture and Education: Social Transformations and Multicultural Communication. Moscow: People's Friendship University of Russia. P. 172-178. https://doi.org/10.22363/09669-2019-172-178.

Bannikova L. N., Baliasov A.A., Kemmet E. V. (2018) Attraction and Retention of Women in Engineering. In: 2018 IEEE International Conference "Quality Management, Transport and Information Security, Information Technologies”. Saint-Petersburg: IEEE. P. $824-827$.

Bannikova L. N., Boronina L. N., Kemmet E. V. (2016). Gender Stereotypes and STEM-Education. In: Proceedings of the 3rd International Multidisciplinary Scientific Conference on Social Sciences and Arts. Book 1. Vol. 2. Albena: Curan Associates, Inc. P. 541-548.

Bannikova L., Petrov A. (2014) Women in Engineering Careers. In: L. G. Chova, A. L. Martinez, I. C. Torres (eds.) ICERI2014: 7th International Conference of Education, Research and Innovation (ICERI). Seville: International Academy of Technology, Education and Development. P. 5270-5275.

Barabanova S. V., Ziyatdinova J., Sokolova A., Ivanov V. G., Sanger P. A. (2013) The Decline of Women in Russian Engineering Education. In: ASEE Annual Conference 
and Exposition, Conference Proceedings. Atlanta: American Society for Engineering Education. P. 23.179.1-23.179.7.

Budnik G. A. (2015) Higher Engineering Education of Women: History and Current Trends. Woman in Russian Society. No. 3/4. P. 37-44. (In Russ.)

Будник Г.А. Высшее инженерно-техническое образование женщин: история и современные тенденции //Женщина в российском обществе. 2015. №3/4. С. $37-44$.

Cannady M. A., Greenwald E., Harris K. N. (2014) Problematizing the STEM Pipeline Metaphor: Is the STEM Pipeline Metaphor Serving our Students and the STEM Workforce? Science Education. Vol. 98. No. 3. P. 443-460. https://doi.org/10.1002/ sce. 21108.

Chernova Z. V. (2019) The Unfinished Gender Revolution. Monitoring of Public Opinion: Economic and Social Changes. No. 2. P. 222-242. https://doi.org/10.14515/ monitoring.2019.2.10. (In Russ.)

Чернова Ж. В. Незавершенная гендерная революция // Мониторинг общественного мнения: экономические и социальные перемены. 2019. № 2. С. 222-242. https://doi.org/10.14515/monitoring.2019.2.10.

Dmitrieva L. G. (2006) Gender Stereotypes of Successful Work (The Case of the Industrial Enterprise). Education and Science. No. 6. P. 101-108. (In Russ.)

Дмитриева Л.Г. Гендерные стереотипы успешной работы (на примере сотрудников промышленного предприятия) // Образование и наука. 2006. № 6. С. 101-108.

Gharibyan H., Gunsaulus S. (2006) Gender Gap in Computer Science does not Exist in One Former Soviet Republic: Results of a Study. In: Proceedings of the 11th Annual SIGCSE Conference on Innovation and Technology in Computer Science Education. New York: Association for Computer Machinery, Inc. P. 222-226.

Grigoreva N.S., Chubarova T. V. (2018) To Leave Impossible to Stay: Life Strategies of Women Who Left STEM-Professions. Woman in Russian Society. No. 4. P. $71-84$. https://doi.org/10.21064/WinRS.2018.4.7. (In Russ.)

Григорьева Н. С., Чубарова Т.В. Уйти нельзя остаться: формирование жизненных стратегий женщин, сменивших STEM-профессии // Женщина в российском обществе. 2018. № 4. С. 71-84. https://doi.org/10.21064/WinRS.2018.4.7.

Ivanova T.V. (2006) Aspects of motivational and personal development of female and male students during studies in technical university (Abstract of the doctoral dissertation in psychology). Nizhnii Novgorod: Nizhnii Novgorod State Pedagogical University. (In Russ.)

Иванова Т.В. Особенности становления мотивационно-личностной сферы юношей и девушек-современных студентов технического вуза в процессе обучения:автореф. дисс. ... канд. психологических наук. Нижний Новгород:НГПУ, 2006.

Kemmet E. V. (2015) Choice of Engineering Profession: Gender Aspect. In: Social and Professional Mobility in XXI Century. Ekaterinburg: RSVPU. P. 54-59. (In Russ.) 
Кеммет Е. В. Выбор инженерной профессии: гендерный аспект / Социальнопрофессиональная мобильность в XXI веке. Екатеринбург: РГППУ, 2015. С. 54-59.

Kemmet E. V. (2017) Professional Self-Determination of Engineering Student: Gender Aspect. Discussion. No. 2(76). P. 55-61. (In Russ.)

Кеммет Е.В. (2017). Профессиональное самоопределение студентов инженерных специальностей: гендерный аспект // Дискуссия. 2017. № 2 (76). С. 55-61.

Kemmet E. V. (2019) Woman Engineer: Social Problems of Employment in the Conditions of Digital Economy. In: Worthy Labor - the Foundation of the Stable Society: Proceedings of XI International Scientific Practical Conference (Ekaterinburg, 30 October 2019). Ekaterinburg: Tipografiya dlya vas, PH Ltd. P. 26-30. (In Russ.) Кеммет Е. В. Женщина-инженер: социальные проблемы занятости в условиях цифровой экономики // Достойный труд-основа стабильного общества: материалы XI Междунар. науч.-практ. конф. (Екатеринбург, 30 октября 2019 г.). Екатеринбург: Изд-во ООО «Типография для Вас», 2019. С. 26-30.

Kemmet E., Bannikova L. (2015) What is the Gender Dimension in the Reproduction of Engineers. In: The 9th International Days of Statistics and Economics: Conference Proceedings. Prague: Melandrium. P. 99-107.

Khasbulatova O.A. (2018) Technologies of Gender Equality Myth Creation: Soviet Practices. Woman in Russian society. 2018. No. 4. P. 49-59. https://doi.org/10.21064/ WinRS.2018.4.5. (In Russ.)

Хасбулатова О.А. Технологии создания мифа о равноправии полов: советские практики // Женщина в российском обществе. 2018. № 4. С. 49-59. https:// doi.org/10.21064/WinRS.2018.4.5.

Kislyakov P.. A., Shmeleva E.. A. (2018) The Digital Gender Gap as a Risk Factor of Social Safety of the Russian Society. Woman in Russian Society. No. 3. P. 14-25. https:// doi.org/10.21064/WinRS.2018.3.2. (In Russ.)

Кисляков П..А., Шмелева Е..А. Цифровой разрыв как фактор риска социальной безопасности российского общества // Женщина в российском обществе. 2018. № 3. C. 14-25. https://doi.org/10.21064/WinRS.2018.3.2.

Kolesnikova E. M. (2018) Engineering Dynasties and Professional Biography Prospects for Students at Technical Institutes and Universities. Sociological Journal. Vol. 24. No. 1. P. 55-72. https://doi.org/10.19181/socjour.2018.24.1.5713. (In Russ.)

Колесникова Е. М. Инженерные династии и перспективы профессиональной биографии студентов инженерных вузов // Социологический журнал. 2018. Т. 24. № 1. С. 55-72. https://doi.org/10.19181/socjour.2018.24.1.5713.

Kolesnikova E. M., Kudenko I. A. (2020) Interest for STEM-Professions at School: Problems of Career Guidance. Sociological Studies. No. 4. P. 124-133. https:// doi.org/10.31857/S013216250009117-1. (In Russ.)

Колесникова Е. М., Куденко И. А. Интерес к STEM-профессиям в школе: проблемы профориентации // Социологические исследования. 2020. № 4. С. 124-133. https://doi.org/10.31857/S013216250009117-1. 
Kovaleva N. (1999) Women and Engineering Training in Russia. European Journal of Education. Vol. 34. No. 4. P. 425-435.

Kozina I. M. (2002) Professional Segregation: Gender Stereotypes on the Labor Market. Sociological Journal. No. 3. P. 126-136. (In Russ.)

Козина И. М. Профессиональная сегрегация: гендерные стереотипы на рынке труда // Социологический журнал. 2002. № 3. С. 126-136.

Kravchenko Z. V., Motejunaite A. (2008) Women and Men in Employment and at Home: Gendered Work Patterns in Russia and Sweden. Journal of Social Policy Studies. Vol. 6. No. 2. P. $177-200$. (In Russ.)

Кравченко Ж. В., Мотеюнайте А. Женщины и мужчины на работе и дома: гендерное разделение труда в России и Швеции // Журнал исследований социальной политики. 2008. Т. 6. № . 2. С. $177-200$

Krekhovets E. V., Leonova L. A. (2017) University Graduates Employability: Gender Analysis. Woman in Russian Society. No. 3(84). P. 58-69. https://doi.org/10.21064/ WinRS.2017.3.5. (In Russ.)

Креховец Е.В., Леонова Л.А. Трудоустройство выпускников высших учебных заведений: гендерный анализ // Женщина в российском обществе. 2017. № 3(84). C. 58-69. https://doi.org/10.21064/WinRS.2017.3.5.

Kuznetsova V.P., Apevalova Z. V., Trofimova I. B. (2020) Public Instruments of Raising the Attractiveness of Engineering Profession for Women. In: Women in Professions of the XXI Century: Trends, Problems, Prospects: Proceedings of All-Russian Scientific Conference with International Participation (Moscow, 03 March 2020). Ivanovo: ISU Publishing house. P. 55-60. (In Russ.)

Кузнецова В.П., Апевалова З. В., Трофимова И. Б. Общественные инструменты повышения привлекательности инженерных профессий для женщин // Женщины В профессиях XXI века: тенденции, проблемы, перспективы: материалы Всероссийской научной конференции с международным участием (Москва, 3 марта 2020). Иваново: Издательство "Ивановский государственный университет", 2020. С. $55-60$.

Lavigne K., Rauvola R. (2018) Bridging Individual and Social-Structural Perspectives. Industrial and Organizational Psychology. Vol. 11. No. 2. P. 331-334.

Lebedeva N. V., Savinskaya O. B. (2019) Biographical Analysis of Women's Career Path in STEM: Manifestation of Discrimination. In: Gender Relations in the Modern World: Management, Economics, Social Policy: Proceedings of the International Scientific Conference (Ivanovo, 16-18 May 2019). Ivanovo: ISU Publishing house. P. 135-141. (In Russ.)

Лебедева Н.В., Савинская О.Б. Биографический анализ карьерного пути женщин в STEM: проявление дискриминации // «Гендерные отношения в современном мире: управление, экономика, социальная политика»: материалы международной научной конференции (Иваново, 16-18 мая 2019). Иваново: Издательство "Ивановский государственный университет», 2019. С. 135-141. 
Lowrie I. P. (2018) Learning Machines: Pedagogy, Academic-Industrial Collaboration, and Knowledge Work in the Russian Data Sciences (Doctoral dissertation). USA (TX): Rice University. URL: https://hdl.handle.net/1911/105563 (accessed: 01.07.2021).

Lykkegaard E., Ulriksen L. (2019) In and Out of the STEM Pipeline - a Longitudinal Study of a Misleading Metaphor. International Journal of Science Education. Vol. 41. No. 12. P. $1600-1625$.

Maloshonok N. G., Shcheglova I. A. (2020) Role of Gender Stereotypes in Student Dropouts of STEM Programs. Monitoring of Public Opinion: Economic and Social Changes. No. 2. P. 273-292. http://doi.org/10.14515/monitoring.2020.2.945. (In Russ.)

Малошонок Н. Г., Щеглова И. А. Роль гендерных стереотипов в отсеве студентов инженерно-технического профиля // Мониторинг общественного мнения: экономические и социальные перемены. 2020. № 2. С. 273-292. http://doi.org/10.14515/ monitoring.2020.2.945.

Mansurov V. A., Yurchenko O. V. (2016) Social Attitudes and Status of Women Engineers in Russia in Transition. In: V. Mansurov (ed.) The Futures We Want: Global Sociology and the Struggles for a Better World. View from Russia. Moscow: RSS. P. 241-246.

Mansurov V. A., Yurchenko O. V. (2017). Women Engineers' Views on Professional Development. In: V. Mansurov (ed.) (Un)Making Europe: Capitalism, Solidarities, Subjectivities: View from Russia. Moscow: RSS. P. 186-193.

Melnikova N. B. (2017) Women in Realization of Soviet Nuclear Project. In: Demographic Potential of EAEU Countries: VIII Ural Demographic Forum. Ekaterinburg: Institute of Economics of Ural Branch of RAS. Vol. 1. P. 118-124. (In Russ.)

Мельникова Н.В. Женщины в реализации советского атомного проекта // Демографический потенциал стран ЕАЭС: VIII Уральский демографический форум. Т. 1. Екатеринбург: Институт экономики УрО РАН, 2017. С. 118-124.

Miner K. N., Walker J. M., Bergman M. E., Jean V. A., Carter-Sowell A., January S. C., Kaunas, C. (2018) From "Her" Problem to "Our" Problem: Using an Individual Lens versus a Social-Structural Lens to Understand Gender Inequity in STEM. Industrial and Organizational Psychology. Vol. 11. No. 2. P. 267-290.

Myasina E. P., Uvarova V.I. Career of Russian Female Engineer: Peculiarities and Problems. In: Professional Career of Women and Challenges of our Time: International Scientific Practical Internet-Conference (1-31 May 2007). Orel: OSTU. P. 65-77. (In Russ.)

Мясина Е.П., Уварова В.И. Карьера российской женщины инженера: особенности и проблемы // Профессиональная карьера женщин и вызовы времени: Междунар. научно-практическая интернет-конференция (1-31 мая 2007). Орел: ОрелГТУ, 2007. С. $65-77$.

Oblova, I. S., Gerasimova I. G., Sishchuk J. M. (2020) Gender Segregation in STEM Education and Careers in Russia. Global Journal of Engineering Education. Vol. 22. No. 2. P. $130-135$. 
Pavlov B.S., Berdnik L. P. (2019) Is it Difficult to Learn and Become an Engineer for a Young Woman Living in Ural. In: S. V. Ryazantsev, V. K. Levashov, T. K. Rostovskia (eds.) December Social and Political Lectures "How do you live, Russia?". Russian Welfare State and Civil Society Realizing the Strategy of Breakthrough: Results and Reserves. Moscow: Perspektiva. P. 288-294. (In Russ.)

Павлов, Б. С., Бердник Л.П. Трудно ли выучиться и стать инженером молодой женщине на Урале // Декабрьские социально-политические чтения "Как живешь, Россия?". Российское социальное государство и гражданское общество в реализации стратегии прорыва: результаты и резервы / под ред. С.В. Рязанцева, В. К. Левашова, Т. К. Ростовской. М. :Перспектива, 2019. С. 288-294.

Pavlov B. S., Berdnik L. P., Bondareva L. N., Sheveleva O. R. (2020) Young Female Engineer on Ural Plant: Professional Status, Work, Family. Russia: Trends and Development Prospects. No. 15-2. P. 663-670 (In Russ.)

Павлов Б. С., Бердник Л. П., Бондарева Л.Н., Шевелева О.Р. Молодая женщинаинженер на Уральском заводе: профессиональный статус, работа, семья // Россия: тенденции и перспективы развития. 2020. № 15-2. С. 663-670.

Podolskaya A. A. (2019) Perceptions of Work-Life Balance by Women Working in STEM Industries (A Rocket-and-Space Industry Case Study). Monitoring of Public Opinion: Economic and Social Changes. No. 3. P. 192-210. https://doi.org/10.14515/ monitoring.2019.3.12. (In Russ.)

Подольская А. А. Восприятие баланса жизни и работы женщинами, работающими в STEM-отраслях (на примере ракетно-космической отрасли) // Мониторинг общественного мнения: экономические и социальные перемены. 2019. № 3. С. 192-210. https://doi.org/10.14515/monitoring.2019.3.12.

Podolskaya A. A. (2020a) Women Engineers in the Russian Rocket and Space Industry: Career Strategies of the Soviet and Post-Soviet Generation. Vestnik of the Institute of Sociology. Vol. 11. No. 1. P. 151-168. https://doi.org/10.19181/vis.2020.11.1.632. (In Russ.)

Подольская А.А. Женщины-инженеры в российской ракетно-космической отрасли: карьерные стратегии советского и постсоветского поколения // Вестник Института социологии. 2020a. Т. 11. № 1. С. 151-168. https://doi.org/10.19181/ vis.2020.11.1.632.

Podolskaya A. A. (2020b) Career Strategies of Female Engineers Employed in Rocket and Space Industry: Goals and Implementation Opportunities. Monitoring of Public Opinion: Economic and Social Changes. No. 5. P. 467-489. https://doi.org/10.14515/ monitoring.2020.5.1671. (In Russ.)

Подольская А. А. Карьерные стратегии женщин-инженеров на предприятиях ракетно-космической отрасли: цели и возможности реализации //Мониторинг общественного мнения: экономические и социальные перемены. 2020б. № 5. C. 467-489. https://doi.org/10.14515/monitoring.2020.5.1671.

Pushkareva N. L. (2010) Women in Russian Science at the End of $20^{\text {th }}$ - Beginning of $21^{\text {st }}$ Century: Quantitative Description. Woman in Russian Society. No. 3. P. 24-35. (In Russ.) 
Пушкарева Н. Л. Женщины в российской науке конца XX - начала XXI века: обобщение количественных характеристик // Женщина в российском обществе. 2010. № 3. С. $24-35$.

Rudenko N. I., Maliushkin R. V. (2021) Mobility and Gender Differences of Russian Engineers Based on the Materials of the Social Network VKontakte. Monitoring of Public Opinion: Economic and Social Changes. No. 3. P. 88-104. https://doi.org/10.14515/ monitoring.2021.3.1723. (In Russ.)

Руденко Н.И., Малюшкин Р.В. Мобильность и гендерные различия российских инженеров по материалам социальной сети "ВКонтакте" / Мониторинг общественного мнения: экономические и социальные перемены. 2021. № 3. С. 88-104. https://doi.org/10.14515/monitoring.2021.3.1723.

Rudenko N., Maliushkin R., Zemnukhova L., Evseeva I., Chernysheva L. (2019) Exploring Russian Engineers: Analysis of Media, Social Networks and Ethnography of Hi-Tech Company (analytic note ed. by O. Bychkova). Saint Petersburg: STS Centre EUSP. URL: https://eusp.org/sites/default/files/archive/sts/Engineers_in_Russia_ January_2019_STS_Center_EUSP.pdf (accessed: 01.07.2021). (In Russ.)

Руденко Н., Земнухова Л., Малюшкин Р., Евсеева И., Чернышева Л. Исследование российских инженеров: анализ СМИ, социальных сетей и этнография технокомпании (аналитическая записка) / под ред. О. Бычковой. Санкт-Петербург: Центр STS ЕУСПб, 2019. URL: https://eusp.org/sites/default/files/archive/sts/Engineers_in_ Russia_January_2019_STS_Center_EUSP.pdf (дата обращения: 01.07.2021).

Rudenko N. I., Maliushkin R. V., Zemnukhova L. V. (2021, forthcoming). Mobility Patterns, Gender Gaps and Cultural Values of Russian Engineers (Using Materials from the Social Network "VKontakte").

Savinskaya O.B., Lebedeva N.V. (2020) Why Women Leave STEM: The Role of Stereotypes. Woman in Russian Society. No. 2. P. 62-75. https://doi.org/10.21064/ WinRS.2020.2.6. (In Russ.)

Савинская О.Б., Лебедева Н. В. Почему женщины уходят из STEM: роль стереотипов //Женщина в российском обществе. 2020. № 2. С. 62-75. https:// doi.org/10.21064/WinRS.2020.2.6.

Savinskaya O. B., Mkhitarian T. A. (2018) STEM as Girls' Professional Choice: Achievements, Self-Esteem, and Hidden Curriculum. Woman in Russian Society. No. 3. P. 34-48. https://doi.org/10.21064/WinRS.2018.3.4. (In Russ.)

Савинская, О. Б., \& Мхитарян Т.А. Технические дисциплины (STEM) как девичий профессиональный выбор: достижения, самооценка и скрытый учебный план // Женщина в российском обществе. 2018. № 3. С. 34-48. https://doi.org/ 10.21064/WinRS.2018.3.4.

Savostina E. A., Smirnova I. N., Khasbulatova O.A. (2017) STEM: Professional Trajectories of the Youth (Gender Aspect). Woman in Russian Society. No. 3(84). P. 33-44. https://doi.org/10.21064/WinRS.2017.3.3. (In Russ.) 
Савостина Е.А., Смирнова И.Н., Хасбулатова О. А. STEM: профессиональные траектории молодежи (гендерный аспект) //Женщина в российском обществе. 2017. № 3(84). C. 33-44. https://doi.org/10.21064/WinRS.2017.3.3.

Shtyleva L. V. (2018) What Causes Gender Gap in Mathematical Education and STEM Employment among Graduates of Russian Schools? Vestnik of Lobachevsky State University of Nizhni Novgorod. Series: Social Sciences. No. 3(51). P. 166-173. (In Russ.) Штылева Л. В. Чем обусловлен гендерный разрыв в математическом образовании и STEM-занятости выпускников российских школ? // Вестник Нижегородского университета им. Н. И. Лобачевского. Серия: Социальные науки. № 3(51). С. 166-173.

Tatarchenko K. (2017) “The Computer Does Not Believe in Tears”: Soviet Programming, Professionalization, and the Gendering of Authority. Kritika: Explorations in Russian and Eurasian History. Vol. 18. No. 4. P. 709-739.

Temkina A. A., Rotkirkh A. (2002). Soviet Gender Contracts and their Transformation in Contemporary Russia. Sociological Studies. No. 11. P. 4-15. (In Russ.)

Темкина А. А. Роткирх А. Советские гендерные контракты и их трансформация в современной России / / Социологические исследования. 2002. № 11. С. 4-15.

Tiunova I. V. (2019) Women in IT: The Case of Tomsk. In: Collection of XV All-Russian (with International Participation) Scientific Conference of Undergraduate and Graduate Students, and Early Career Scholars (Tomsk, 29-30 April 2019). No. 15. Tomsk: TSU Publishing house. P. 128-132. (In Russ.)

Тиунова Я.В. Женщины в IT: Томский кейс // Сборник материалов XV Всероссийской (с международным участием) научной конференции студентов, магистрантов, аспирантов и молодых ученых (Томск, 29-30 апреля 2019 г.). Выпуск 15. Томск: ИД ТГУ, 2019. С. $128-132$.

Tiunova I. V. (2020) Career and Gender: The Case of IT-Community in Tomsk (Bachelor Diploma Work on Anthropology and Ethnology). Tomsk: National Research Tomsk State University. (In Russ.)

Тиунова Я. В. Карьера и гендер: кейс томского it-сообщества // Выпускная бакалаврская работа по направлению подготовки: 46.03. 03 - Антропология и этнология. Томск: НИ ТГУ, 2020

Uvarova V. (2009). Women in Engineering Research in the Russian Federation: Place, Role, Problems. Lyčiu Studijos ir Tyrimai. No. 6. P. 30-35.

Uvarova V. I., Myasina E. P. (2007) Women's Intellectual Capital in Russian Engineering. In: A. V. Bezgodov (ed.) Intellectual Capital - the Basis of Leading Innovation. Saint Petersburg: Planetarnyi proekt. P. 29-42. (In Russ.)

Уварова В. И., Мясина Е. П. Женский интеллектуальный капитал в российском инжиниринге // Интеллектуальный капитал - основа опережающих инноваций: монография / под общ. ред. А. В. Безгодова. СПб.: Планетарный проект, 2007. С. 29-42.

Varshavskaya E. I., Kotyrlo E.S. (2019) Graduates in Engineering and Economics: Between Demand and Supply. Educational Studies. No. 2. P. 98-127. https://doi.org/10.17323/ 1814-9545-2019-2-98-128. (In Russ.) 
Варшавская Е. Я., Котырло Е. С. Выпускники инженерно-технических и экономических специальностей: между спросом и предложением // Вопросы образования. 2019. № 2. с. 98-127. https://doi.org/10.17323/1814-9545-2019-2-98-128.

Vysotskaia M. A., Rusina C.I. (2012) Research of Learners' Gender Differences in the University by Example of Road Engineering Students. Innovation in Science. No. 13-2. P. 23-32. (In Russ.)

Высоцкая М.А., Русина С. Ю. Исследование гендерного различия обучающихся в вузе на примере инженеров-дорожников // Инновации в науке. № 13-2. C. $23-32$.

Zakharova E. K., Mkhitarian T. A., Savinskaya O. B. (2017) Women in STEM in Digital Era: Employment Policies in the City. Moscow: Variant. https://doi.org/10.13140/ RG.2.2.13552.76809. (In Russ.)

Захарова Е. К., Мхитарян Т. А., Савинская О.Б. Женщины и STEM в цифровую эпоху: политика занятости в мегаполисе. М.: Вариант, 2017. https://doi.org/10.13140/ RG.2.2.13552.76809.

Zdravomyslova E. A., Temkina A. A. (1997) Social Construction of Gender and Gender System in Russia. In: Proceedings of the First Russian Summer School of Women's and Gender Studies “Valdai-1996”. Moscow: Moscow Centre of Gender Studies. P. 84-89. (In Russ.)

Здравомыслова Е. А., Темкина А. А. Социальная конструкция гендера и гендерная система в России // Материалы Первой Российской летней школы по женским и гендерным исследованиям “ВАЛДАЙ-96". М. : Московский центр гендерных исследований, 1997. С. 84-89.

Zemnukhova L. V., Guseva A. A. Socio-Technical Factors of Testers' Liminal Position. The Journal of Sociology and Social Anthropology. Vol. 22. No. 6. P. 69-85. (In Russ.) Земнухова Л. В., Гусева А. А. (2019). Социотехнические факторы лиминальной позиции тестировщиков программного обеспечения / / Журнал социологии и социальной антропологии. Т. 22. № 6. С. 69-85. 